Pedro Gómez (1)

Monasterio de Nuestra Señora de la Paz

San Agustín, Córdoba, Argentina

\title{
"Accende lumen sensibus" -Una aproximación filosófico-teológica a la doctrina de los sentidos espirituales en la teología monástica medieval-
}

Al leer con atención y frecuentar con meditación asidua los textos de los autores monásticos medievales nos encontramos con reiteradas referencias a los "sentidos espirituales" (2), "sentidos del corazón", "sentidos del hombre interior", "sentidos del alma", o "sentidos divinos". Porque así como hay sentidos que son propios del cuerpo, que quedan afectados al entrar en contacto con la realidad corpórea, hay otros que residen en el espíritu (3), y que actúan cuando tienen relación con lo espiritual, constituyendo una sensibilidad específica (4), siendo "al mismo tiempo la consumación de los sentidos naturales (gratia perficit naturam) y una sensibilidad completamente nueva, infundida por la gracia, para captar las formas de manifestación de lo divino en el mundo" (5), y describiendo a grandes rasgos los niveles de su experiencia (6).

Se trata de un modo de conocer a Dios que es distinto del conocimiento racional (filosofía), diverso incluso del de la razón iluminada por la fe (teología), y que puede ser llamado "conocimiento experimental" (7) (mística). Y como "el principio de la teología monástica fue siempre el siguiente: no afirmar con la boca a no ser lo que antes se ha experimentado con la vida" (8), intentaremos aproximarnos a los

(1) Monje del Monasterio de Nuestra Señora de la Paz, San Agustín, Córdoba, Argentina.

(2) Cf. M. Olphe-Galliard, "Le sens spirituel dans 1' spirituel dans l'histoire de la spiritualité", en Nos sens et Dieu, Ét. Carmélitaines, Desclée de Brouwer, 1954, pp. 179-193.

(3) La antropología monástica distinguía-unía el cuerpo, el alma y el espíritu (cf. 1 Ts 5, 23-24).

(4) Cf. P. Gelabert, Dios con los cinco sentidos, Zenith, Barcelona, 2005; A. Grün, Para experimentar a Dios abre tus sentidos, Lumen, Bs. As., 2002; I. Gómez-Acebo (Ed.), Cinco mujeres oran con los sentidos, Descleé de Brower, Bilbao, 1997.

(5) H. U. v. Balthasar, "Ver, oír, leer en el ámbito de la Iglesia", en Ensayos teológicos II, Sponsa Verbi, Cristiandad, Madrid, 1964, p. 567.

(6) Cf. M. Canévet, "Sens spirituel", en Dictionnaire de Spiritualité Ascétique et Mystique Doctrine et Histoire, v. 15, Beauchesne, Paris, 1989, 598-617.

(7) Cf. J. E. Rivera, "Los sentidos espirituales en la mística medieval”, Philosophica 7 (1984), p. 157.

(8) T. Spidlik, "Ritmos y antinómias espirituales", Cuad. de Espiritualidad y Teología 20 (1998), p. 37. Cf. San Anselmo de Cantorbery, Carta sobre la encarnación del Verbo, Dedicatoria al papa Urbano II, Obras completas I, BAC, Madrid, 1952, pp. 685.693.695. 
sentidos espirituales a partir de algunos testimonios de los siglos XI al XIII (I), especialmente los referidos a la lectio divina (II. 1) y al opus Dei (II. 2), puntos de partida de su "intellectus fidei".

En "el más famoso de los himnos" (9) que la Iglesia continúa cantando en la liturgia y en los actos académicos, y que probablemente fue compuesto por un monje en el siglo IX (10), encontramos una frase que sintetiza bellamente lo que estos hombres y mujeres deseaban e imploraban: "Accende lumen sensibus" (III).

\section{SENTIDOS ESPIRITUALES PARA EXPERIMENTAR A DIOS}

El teólogo suizo Hans Urs von Balthasar distingue en la historia de la teologíaespiritualidad tres fases en las que se trató de un modo original la cuestión de los sentidos espirituales y que dieron origen a corrientes muy influyentes a lo largo del tiempo. La primera es el momento patrístico que comienza, como lo ha mostrado también Karl Rahner (11), con Orígenes (12), continúa con Evagrio Póntico y se profundiza en el Pseudo-Macario (13); y que en Occidente pasa por san Agustín de

(9) Cf. Frere, Introduction to Hymns Ancient and Modern, London, 1909.

(10) Dreves en "Lateinische Hymnendichter des Mittelalters" II, Analecta Hymnica L (1907), p. 195, coloca el himno en la sección dedicada a Rabano Mauro abad de Fulda y arzobispo de Maguncia; Frere en su Introducción a los Himnos antiguos y modernos cree que puede "con alguna confianza" serle atribuido, como lo hace Blume en "Ein neuer Markstein in der liturgischen Hymnodie", Stimmen aus Maria-laach, LXXV, 1 (1908), y Duffield en Latin Hymn-Writers and their Hymns, New York, 1889, pp. 114-131. Confirmación adicional se encuentra en la escansión de la línea Qui Paracletus dicit, donde, en concordancia con lo precedente encontrado en Rabano, Paracletus se acentúa en la penúltima sílaba, en contra de la costumbre medieval casi universal de acentuarlo en la antepenúltima. Dom Guéranger atribuyó el himno a Carlomagno, pero con muy pobres fundamentos. La historia legendaria de Ekkehard V contiene su propia refutación. El himno ha sido atribuido también a san Ambrosio y a san Gregorio Magno, pero sin evidencia real para una u otra atribución. Cf. Oit, "L’Innodia ambrosiana”, Rassegna Gregoriana VI (1907).

(11) Cf. K. Rahner, "Le début d'une doctrine des cinq sens spirituels chez Orígenes", Revue d'ascétique et de mystique 13 (1932), pp. 113-145.

(12) En su De Principiis escribe: "El que haga un examen más hondo afirmará que existe, como lo ha denotado la Escritura, un sentido genérico divino; tan solo el bienaventurado podrá hallarlo, tal como está escrito: "Encontrarás el sentido divino". De tal sentido hay diferentes especies: una vista para contemplar los objetos supercorpóreos, como es manifiestamente el caso para los querubines y los serafines; un oído capaz de distinguir voces que no resuenan en el aire; un gusto para saborear el pan vivo bajado del cielo para dar la vida al mundo; asimismo un olfato que perciba lo que llevó a Pablo a decir el buen olor de Cristo; un tacto que poseía Juan cuando palpó el Verbo de Vida” (citado por J. Daniélou, Orígenes, Sudamericana, Bs. As., 1958, pp. 375-76. Cf. Contra Celso 1, 48; SCh 132, pp. 202-204). Define su objeto: Cristo (cf. Comentario al Cantar de los Cantares, II, 9, 12-13; Ciudad Nueva, Madrid, 1994, pp. 197-198); y los contrapone a los corporales (cf. Idem, I, 4, 16, p. 103), explicando cómo el hombre debe ir mortificando los sentidos carnales, para que así puedan ir creciendo los del "hombre interior", hasta que cautiven por completo al alma y la hagan salir fuera de sí, en el éxtasis, con lo cual las cosas ya no tendrán sabor (cf. Idem, I, 4, 11-12, pp. 101-103).

(13) Cf. H. U. v. Balthasar, Gloria, Una estética teológica, 1. La percepción de la forma, Encuentro, Madrid, 1985, pp. 240- 246 y 327 ss. El desarrollo de los sentidos espirituales va de la mano con el crecimiento de la vida espiritual, idea desplegada por Gregorio de Nisa, quien establece una jerarquía entre los distintos sentidos, correspondiendo cada uno a una etapa del "ascenso místico". Cf. J. Daniélou, Platonisme et théologie mystique, Essai sur la doctrine spirituelle de Saint Grégoire de Nysse, Aubier, Paris, 1944, pp. 235-266. El Pseudo-Macario, Diadoco de Fótice, 
Hipona (14) y san Gregorio Magno; la segunda es la fase medieval que "se caracteriza en su totalidad por el hecho de que (en la medida en que la psicología escolástica se consolida filosóficamente) interpreta claramente los sentidos espirituales como expresión de la experiencia místico-intuitiva de Dios" (15), como sucede en Bernardo de Claraval, Guillermo de Saint Thierry, Alquerio de Claraval, la Escuela de san Víctor, y san Buenaventura; y la tercera se sitúa en el inicio de la edad moderna (16) con los Ejercicios Espirituales de san Ignacio de Loyola (17).

Recordaremos solo dos testimonios de la primera fase: uno griego y otro latino. Orígenes en un hermoso texto, conocido en la Edad Media a través de la Glossa ordinaria y que ejerció gran influencia en las teologías medievales (18), hablando de los sentidos espirituales decía:

"Por medio de ellos vemos a Dios, si tenemos ya limpio el corazón, por ellos adquirimos oídos para escuchar lo que nos enseña Jesús, percibimos el aroma de que habla el Apóstol cuando afirma que "somos el buen olor de Cristo para Dios", podemos gustar lo que nos dice el Profeta: "Gustad y ved que bueno es el Señor", y recibimos ese tacto a que se refiere san Juan: "lo vimos con nuestros ojos y nuestras manos palparon al Verbo de la vida”...” (19).

Y san Agustín en sus Confesiones cuenta su propia experiencia:

"Me llamaste, me gritaste y rompiste mi sordera. Brillaste, y tu resplandor hizo desaparecer mi ceguera. Exhalaste tus perfumes y respiré hondo, y suspiro por Ti. Te he saboreado, y me muero de hambre y de sed. Me has tocado, y ardo en deseos de tu paz" (20).

Los teólogos monásticos han asimilado y transmitido esta herencia patrística, la han repensado con cierta originalidad recurriendo a las herramientas intelectuales (gramática y retórica) disponibles en su tiempo, y la han comunicado con un lengua-

Máximo el Confesor, y Simeón el Nuevo Teólogo, proponen toda una pedagogía de los sentidos espirituales, en relación con la vida sacramental. Se trata siempre de elevarse dialécticamente, en el sentido platónico, del ámbito sensible hacia el reino que está "más allá de los sentidos", "ir de estas realidades que pasan hacia la realidad que no pasa". Los sentidos corporales no son destruidos, sino transfigurados, devienen sentidos espirituales, que vuelven al hombre "capax Dei".

(14) Cf. In Ioann. Evang. XVII, 10.

(15) Cf. Gloria, Una estética teológica, 1. La percepción de la forma, op . cit., p. 330.

(16) El oscurecimiento de esta doctrina tradicional empezó a notarse a finales del siglo XV, se acentuó en el XVII y llegó a su extremo en el XVIII, Cf. J. G. Arintero, Cuestiones místicas, BAC, Madrid, 1956, p. 56.

(17) "El tercer método de oración en los Ejercicios Espirituales se llamó la aplicación de los cinco sentidos. Consiste en aplicar sucesivamente los cinco sentidos al objeto de la meditación, espiritualmente. Este método está diseñado para preparar a los principiantes para la contemplación en el sentido tradicional de la palabra y para promover el desarrollo de los sentidos espirituales en aquellos más avanzados en la oración" (T. Keating, Mente abierta, corazón abierto, La Dimensión Contemplativa del Evangelio, Continuum, New York, 2001, p. 15).

(18) Cf. Santo Tomás de Aquino, In III Sent. dist. 3, expositio textus.

(19) In Lev, III, 7.

(20) Confesiones, X, 27, 38, Bonum, Bs. As., 2003, p. 233. 
je simbólico propio, inspirado en la lectio divina y la liturgia, señalando de manera explícita la relación entre los sentidos espirituales y el conocimiento experimental de Dios (21), haciendo "presente directamente, en el modus del sentido sensible, el modus del sentido espiritual-pneumático" (22).

Cuando un monje percibía la presencia-visita de Dios no la experimentaba siempre de la misma manera, sino con diversos matices, por lo que la asociaba espontánea y analógicamente a uno u otro de los sentidos corporales (23). Aún más, cada uno de sus sentidos exteriores tenía su gemelo en la parte interior del alma, allí donde esta se abría al espíritu. Su vida espiritual consistía en mirar con los ojos externos y ver con los espirituales. La misma realidad vista con los ojos corporales se leía interiormente como una realidad espiritual, y llegaba a ser lo que realmente era: una realidad y un signo (24).

Al progresar en la vida monástica y en la fe, se dilataba su corazón (25) y las sensaciones externas e internas se unificaban por la acción del Espíritu Santo (26), por eso se puede afirmar que "la espiritualización de los sentidos es la verdadera espiritualización del espíritu” (27). Lamentablemente "la mística moderna, que parte de lo psicológico -al no fijarse, muchas veces, en los fundamentos teológicos de la mística- abandona la doctrina de los sentidos del espíritu, que propugna una espiritualización -una actualización de los sentidos bajo la moción del Espíritu Santo-, y no precisamente la existencia de sentidos en el espíritu en contraposición de los del alma" (28).

A primera vista parecería que al hablar de "sentidos espirituales" estos autores estarían usando una metáfora, si no sería una contradictio in adiecto -la atribución a un sustantivo de un adjetivo que contradice su significado-, para referirse a los actos de la inteligencia y de la voluntad elevados por la gracia, los cuales se diversificarían según los distintos objetos a que van dirigidos. Pero recordemos que en el siglo XII se hablaba habitualmente de un sensus spiritualis, en contraposición a un sensus carnalis, de un sensus cordis, un sensus animae y un sensus intellectualis, porque los sentidos espirituales eran modalidades de un conocimiento intelectivo de carácter experimental (29).

No se trata entonces de una simple metáfora, sino de una analogía donde lo semejante no es lo "sensorial", sino la "impresión" de la realidad. Los mismos

(21) Cf. San Alberto Magno, In III Sent. dist. 13, art. 4; De coelesti Hier., 15, 5.

(22) H. U. v. Balthasar, "Ver, oír, leer en el ámbito de la Iglesia", op. cit., p. 567.

(23) Cf. San Agustín de Hipona, Confesiones X, 6, 8, pp. 211-212.

(24) "Habent corpora omnia ad invisibilia bona similitudinem" (Ricardo de San Víctor, Benjamin major, PL 196, 90). Cf. U. Eco, Arte y belleza en la estética medieval, Lumen, Barcelona, 1997, pp. 68-99.

(25) Cf. San Benito, Regla de los monjes (RB), Pról. 49.

(26) Cf. M. I. Rupnik, En el fuego de la zarza ardiente, Iniciación a la vida espiritual, PPC, Madrid, 1998 , p. 59.

(27) J. Ratzinger, La fiesta de la fe, Ensayo de teología litúrgica, Desclée de Brower, Bilbao, 1999, p. 160 .

(28) A. Stolz, Teología de la mística, Rialp, Madrid, 1952, p. 248.

(29) Cf. J. E. Rivera, op. cit., p. 161.

(30) La diversidad de tales ángulos de acceso no es indiferente para la realidad percibida misma. Cf. H. U. v. Balthasar, "Ver, oír, leer en el ámbito de la Iglesia”, op. cit., p. 561. 
nombres de los sentidos son gramaticalmente participios pasivos sustantivados: tactus, odoratus, auditus, gustus, visus; porque no hay sensación sin algo externo que los impresione, para que ellos puedan reproducirlo en sí mismos conforme a su sesgo específico (30). En el conocimiento experimental la inteligencia del hombre se comporta pasivamente, es decir, padece, experimenta las cosas de Dios, ya el Pseudo Dionisio hablaba de "pati divina" (31). Este padecer, pathos y sapor, es analógicamente un sentir, y a este sentir se lo llama experiencia (32), que testimoniada y descripta, es la fuente, el presupuesto, la garantía y el culmen del "saber sabroso" de los monjes medievales, como una clave de interpretación complementaria a la fe y a la razón.

El adjetivo "espirituales", por su parte, nos recuerda que no se los puede definir con exactitud, ya que estas realidades solamente pueden ser descriptas negativamente o mediante símbolos que nos las sugieren, que nos dicen como serían, pero sin decirnos lo que son. Por eso fueron entendidos de forma alegórica y mística. San Bernardo suele hablar alegóricamente, aunque no siempre, en particular por lo que se refiere al sentido del gusto; y Guillermo de Saint Thierry lo hace unas veces en sentido alegórico y otras en sentido propiamente místico:

“El alma tiene también sus sentidos, como los tiene el cuerpo... Como los cinco sentidos corporales son el lazo de unión entre el cuerpo y el alma, los sentidos espirituales aseguran por la caridad la unión entre el alma y Dios. Por lo cual, dice el apóstol: "No os conforméis a este siglo sino transformaos por la renovación de vuestros sentidos. Para que sepáis discernir cuál es la voluntad de Dios, buena, grata y perfecta” (Rm 12, 2). El texto nos da entender que por los sentidos corporales envejecemos conformándonos al mundo, mientras que por los sentidos del alma nos rejuvenecemos por el conocimiento de Dios en vista de una vida nueva, conforme a la voluntad y al beneplácito de Dios” (33).

"Solamente allí, dice K. Rahner, donde a la tradición se añade una experiencia mística inmediata y un vivo interés por el significado de estos sentidos, se intenta darles una interpretación realmente importante para la teoría mística. Es lo que

(31) "Hierotheus est perfectus in divinis, non solum discens sed en patiens divina".

(32) "La experiencia es, literalmente, el saber que se adquiere al viajar. La misma raíz nos da el latín per (a través), de donde peligro (la travesía temible), experto (el que ha ido al fondo de las cosas); el alemán fahren (viajar), de donde viene Erfahrung (experiencia); el griego peira (tentativa, tentación, prueba, experiencia)” (H. U. v. Balthasar, “Experiencia de Dios?”, Criterio 1932 (1984), p. 549, n. 2). Remite a la raíz por-perior y por ello implica por tres áreas de sentido. Se remonta al conocimiento inmediato y directo del peritus, que conoce por con-tacto. Además, al conocimiento riesgoso, problemático, siempre experto del periculum, el encuentro con la resistencia, con la dureza de la alteridad, con la prueba. Y finalmente, a la raíz de puerta-puerto, es decir de umbral, donde siempre y continuamente se pasa de la experiencia del peritus a la experiencia del periculum y viceversa. Cf. B. Forte, "Coloquio: Sobre el comienzo y el fin de la historia", Azzurra 7-9 (1996), p. 47.

(33) Guillermo de Saint Thierry, Naturaleza y dignidad del amor 19, en Carta a los hermanos de Monte Dei y otros escritos, Sígueme, Salamanca, 1995, p. 178. 
ocurre en san Buenaventura" (34). En él encontramos reunidas la experiencia monástica y la ciencia escolástica, la mística y la filosofía. "Los sentidos espirituales no son... facultades espirituales distintas de la inteligencia y la voluntad, sino actos particulares de estas mismas facultades, es decir, los actos en que tiene lugar la contemplación, el conocimiento experimental y sabroso de las cosas de Dios" (35).

Por ejemplo en el Itinerarium el Doctor Seráfico establece con profundidad y finura la unión entre "sentidos espirituales" y "virtudes teologales" (36). Estos constituirían así una segunda sensibilidad, situada junto a la corporal y superior a ella, en cuanto a sus actos, con la que el espíritu experimenta de un modo sensible a Dios, teniendo por objeto la Palabra en su economía, como Verbum increatum, por el oído y la vista, inspiratum, por el olfato, incarnatum, por el gusto y el tacto.

"Es verdad -afirma Enzo Bianchi- que la doctrina tradicional de los sentidos espirituales se funda a veces en la contraposición y ruptura entre sentidos corpóreos y sentidos espirituales; pero en ciertas modulaciones (por ejemplo, en san Buenaventura) se percibe la continuidad entre los dos niveles de sentidos. De todos modos, y más allá de las antropologías que subyacían en las antiguas formulaciones doctrinales, es esencial recuperar y reformular la realidad profunda que expresaban" (37). Porque no se puede pretender que los sentidos espirituales tengan valor tan solo para la percepción, experiencia sensitiva-afectiva, de Dios y no para su conocimiento (38). Ambas cosas, como dice Juan Gerson (39), van juntas. Si no fuera la unión mística también conocimiento, en manera alguna podría ser el entendimiento el órgano de la ascensión del espíritu, como puede verse claramente en Ricardo de San Víctor (40). Por eso algunos especialistas apoyados en el análisis de los múltiples testimonios sobre los sentidos espirituales establecen la afirmación de un conocimiento inmediato de Dios en el estado místico (41).

La experiencia mística es un conocimiento, esta afirmación tira por tierra lo dicho por José Ortega y Gasset: "Mi objeción al misticismo es que la visión mística no redunda beneficio alguno intelectual" (42), porque "cualquier teología me parece transmitirnos mucha más cantidad de Dios, más atisbos y nociones sobre la divinidad, que todos los éxtasis juntos de todos los místicos juntos (43). Tal vez el filósofo español tenga alguna razón en lo referido a la cantidad, pero no así a la cualidad.

(34) K. Rahner, "Die Lehre von den "geistlichen Sinnen" im Mittelalter", Schriften zur Theologie 12, Freiburg, 1975, p. 140.

(35) J. E. Rivera, op. cit., p. 159. Dedica particularmente a san Buenaventura las pp. 163-176.

(36) Cf. San Buenaventura, Itinerarium mentis in Deum, IV 3. El itinerario de la mente hacia Dios, C.C.C., Bs. As., 1934, pp. 99.101; K. Rahner, "Die Lehre von den "geistlichen Sinnen" im Mittelalter", op. cit., pp. 137-172.

(37) E. Bianchi, Palabras de la vida interior, Sígueme, Salamanca, 2006, p. 30.

(38) "Y el apremio de representarlos -comparándolos con los sentidos del cuerpo- parece indicar que se trata de un conocimiento inmediato de Dios, al igual que los sentidos aprehenden directamente su objeto" (A. Stolz, op. cit., p. 164).

(39) Cf. K. Richstätter, Mystische Gebetsgnaden, 1924, p. 198.

(40) Cf. J. Bernhart, Die philosophische Mystik des Mittelalters, 1922, p. 116.

(41) Cf. A. Stolz, op. cit., p. 165.

(42) Defensa del teólogo frente al místico (1929), en Obras Completas 5, Revista de Occidente, Madrid, 1970, p. 455.

(43) Idem., p. 456. 
Recordemos que para los medievales existían tres fuentes para el conocimiento de Dios. En primer lugar la realidad de las cosas naturalmente cognoscible por la razón, es decir: los efectos de Dios, y aquí los sentidos físicos o externos jugaban un papel insustituible como "facultad cognitiva" (44) por la que se lo conoce "per speculum”, es decir, metafísicamente -experiencia madura de la razón-, como lo afirma un monje anónimo del siglo XII:

"Las ventanas son... los cinco sentidos del cuerpo... A través de estas ventanas el hombre interior ve lo exterior, conoce lo que ve, y desea lo que conoce. Dios, que creó esta casa corporal, dispuso la organización del cuerpo para que el hombre conociera así las cosas visibles y a través de este conocimiento llegara a conocerlo a él, como a la luz más necesaria” (45).

La segunda son las palabras y acciones que revelan a Dios y su designio de salvación, en otros términos, los testimonios sobre Él, asentados en la experiencia, expresados de acuerdo al lenguaje humano, y aceptados por la fe, que les llegaban por los sentidos físicos y espirituales. "Su fundamento no es ya la evidencia del objeto conocido, sino la veracidad del testigo que nos las hace conocer... Y esto no es una forma inferior de conocimiento, sino, por el contrario, el conocimiento por excelencia" (46). Dice 1 Corintios 13, 12: "Videmus nunc per speculum in aenigmate... Nunc cognosco ex parte...”, y 2 Cor 5, 7: “per fidem enim ambulamus, et non per speciem”, y "esto muestra cómo la revelación de Dios se entrega a los hombres con la ayuda de símbolos e imágenes; y que siempre será necesario, para recibirla, abrir los ojos de la inteligencia y del corazón" (47), en palabras de san Bernardo:

"El oído escucha lo que no pueden percibir los ojos... Ahora, en cambio, el remedio entrará por donde entró la enfermedad... Así el ojo enturbiado curará y verá, ya sano, al que no podía ver, irritado. El oído ha sido la primera puerta por la que entró la muerte y será la primera en abrirse a la vida; el oído, que nos dejó ciegos, nos devolverá la vista; porque sino creemos, no comprenderemos" (48).

Este comprender lo creído no es otra cosa que la theologia, experiencia madura de la fe, como afirma san Anselmo: "Inter fidem et speciem intellectum quem in hac vita capimus esse medium intelligo" (49).

(44) Cf. Santo Tomas de Aquino, Summa Theologiae I, 5, 4 ad 1.

(45) Liber de Stabilitate Animae, cap. III, PL 213, 911-930. Traducción de M. Demateis, osb, en "Los ojos y los demás sentidos según un anónimo benedictino del siglo XII”, Coloquio 13 (2001), p. 19.

(46) J. Danielou, Dios y nosotros, Taurus, Madrid, 1957, p. 87.

(47) C. M. Martini, Invitación a la belleza. Discursos sobre el arte, Lumen, Bs. As., 2006, p. 66.

(48) San Bernardo de Claraval, Sermones sobre el Cantar de los Cantares 28, 5, Obras completas V, BAC, Madrid, 1987, p. 411.

(49) San Anselmo, De fide Trinitatis, Praef.; PL 158, 61. 
Y por último, la tercera fuente es la experiencia directa de la realidad misma de Dios, donde actúan los sentidos espirituales. Se trata de una profundización del conocimiento por la fe, no en cuanto al objeto conocido sino según la forma de conocerlo. En la mística la misma forma del conocimiento es sobrenatural. Esta experiencia "teopática", fruto de la gracia, tenía lugar ordinariamente junto con un sentir corpóreo, pero esta materialidad no formaba parte de ella sino en un sentido instrumental. Por eso podemos afirmar que esta doctrina se ubica entre el espiritualismo desencarnado (50) y el sensualismo empirista (51). Es un "conocer experimental" que se da con el sensible, pero no en él y por él, estamos pues el extremo opuesto de la abstracción científica. Se conoce directa y pasivamente a Dios por su acción en el alma, lo conocemos "in speculum”, según lo dicho por Guerrico de Igny:

“...para que esto suceda, es decir, para que veamos como en un espejo, es preciso no solo que la superficie de nuestro espejo esté exenta de toda imagen y sombra de las cosas corporales, sino también que el ser sublime que habita en una luz inaccesible se digne inclinarse hasta nosotros y manifestársenos, al menos por la sombra de su imagen... la sombra no se ve si ella no se inclina, y se dice que se inclina solo cuando aparece el día, porque no podemos ver a Dios ni en espejo ni en imagen si su majestad no se inclina y no aparece el favor de su gracia” (52).

Teniendo en cuenta estas coordenadas se podría plantear ahora la compleja cuestión de la relación entre la mística y la filosofía: "Cuando el problema reemplaza al misterio, como sucede muy fácilmente en las ontologías de la esencia, la metafísica se reduce a un tejido de abstracciones; pero cuando el misterio devora el problema, la ontología se pierde en la mística" (53). Lo problemático e importante, a la vez, es mantener estas dos actividades espirituales que enaltecen a la naturaleza humana. "Nada se gana -afirmaba Étienne Gilson- con destruir la una para salvar a la otra, porque duran o caen juntas. Sin una Teología no hay misticismo verdadero, y toda Teología sana busca el soporte de una Filosofía” (54). La relación entre conocimiento "in speculum" y "per speculum" es siempre mediada por la teología. El juego de relaciones entre los tres órdenes para los medievales era: primero entre

(50) “... la espiritualización cristiana no es simplemente lo opuesto al mundo de los sentidos, como la mística del platonismo, sino un ir hacia el Señor que es Espíritu. Por eso el cuerpo va incluido en esta espiritualización: El Señor es el Espíritu ya que es precisamente Aquel cuyo cuerpo no se corrompe, sino que fue inundado de la fuerza de vida del Espíritu. La cristología marca la diferencia fundamental respecto a la doctrina platónica de la espiritualización; pero entre sus antecedentes está la teología de la creación, cuya unidad interna se ve confirmada, y no anulada..." (J. Ratzinger, op. cit., p. 146).

(51) Que hace de la sensación el origen y el límite del conocimiento.

(52) Guerrico de Igny, Sermón 46, En la festividad de San Pedro y San Pablo III, Las sombras y la luz 4, en La Luz de Cristo, Homilías para el año litúrgico, Monasterio Trapense de Azul-Claretiana, Bs. As., 1983, p. 410; Cf. Sermón 2, Adviento II, De la manera de salir al encuentro de Cristo 4, p. 78.

(53) É. Gilson, "El tomismo y las filosofías existenciales", Sapientia 4 (1954), p. 239.

(54) É. Gilson, La unidad de la experiencia filosófica, Rialp, Madrid, 1973, p. 49. 
teología y filosofía, luego teología y mística (55), y en tercer lugar filosofía y mística (56).

El P. Arintero, op, un teólogo neoescolástico especialista en cuestiones místicas (57), afirma que: "aunque el nombre de sentidos sea metafórico y les venga solo de cierta remota analogía que tienen con los corporales, sin embargo la realidad de sus espiritualísimas impresiones o percepciones es indiscutible" (58). Y agrega que, según la mayoría de los teólogos y místicos, los dones de la sabiduría y la inteligencia "nos permiten percibir de algún modo lo divino, rasgando un poquito el velo del misterio, y dándonos así un conocimiento intermedio entre el de la fe y el facial o beatífico, y que, a semejanza de este último nada tiene que ver con el ontologismo" (59). Se trata de un conocimiento oscuro, fundado en la fe, e inmediato, obra de la gracia, que no encierra en sí necesariamente una visión inmediata y clara de la esencia divina, que excluye nuestro estado actual (60). "Y por ello es justo, más aún, necesario -como afirma von Balthasar- que estos modi sensibles desempeñen un papel tanto en el conocimiento natural analógico de Dios como en las revelaciones sobrenaturales de Dios a los hombres" (61).

Para los monjes medievales los sentidos, el sentir y la sensación se integraban en el conocimiento de Dios. Conocimiento experimental, integral, fiducial, sapiencial, sacramental y místico, que "se dilata hasta llegar a entrar dentro de las demás potencias y, como resultado, unifica toda la persona en torno al misterio de Dios" (62). Porque como escribe André Louf, ocso, comentando la célebre frase gregoriana: "Amor ipse notitia est" (63): "El amor mismo se ha hecho conocimiento, no porque sustituya al entendimiento, sino porque abraza al entendimiento desde el interior, como el fuego se incuba bajo la ceniza. Lo que vale para el entendimiento, vale también para las demás potencias" (64), incluidos los sentidos espirituales.

(55) Teólogos contemporáneos católicos, como los dos Rahner, Von Balthasar, De Lubac, Daniélou, Congar, Chenu, Leclercq, Teilhard y Bernard; protestantes, por ejemplo Barth y Bonhoeffer; y ortodoxos, por caso Evdokimov, buscaron de diversas maneras superar la ruptura entre una teología, que se había vuelto más racionalista-cientificista y menos experiencial-sapiencial, y una mística, cada vez menos reflexiva-especulativa y más afectiva-emotiva, invirtiendo los signos.

(56) Filósofos contemporáneos como Heidegger, Wittgentein, Pániker, Zambrano, Vaninni, Salmann y Haas replantean la relación de la filosofía con la mística como posible salida al positivismo, escepticismo y nihilismo, volviendo su mirada a los griegos, Eckhart o las místicas del oriente medio y lejano.

(57) Cf. J. G. Arintero, La evolución mística en el desenvolvimiento y vitalidad de la Iglesia, Fides, Salamanca, 1944, pp. 488-502.

(58) J. G. Arintero, Cuestiones místicas, op. cit., p. 48.

(59) Idem, pp. 49-50. Cf. p. 54s; "Así, pues, los sentidos espirituales de la vista y del oído se refieren al don de entendimiento, por el que vemos a Dios y las cosas divinas..., y oímos a Dios que nos habla al corazón. Los otros tres sentidos se refieren al don de sabiduría, con el que gustamos a Dios, aspiramos u olemos el perfume de sus perfecciones, y tocámosle por una especie de estrecha unión y abrazo espiritual, que no es sino un amor experimental de Dios" (A. Tanquerey, Compendio de Teología ascética y Mística, Desclée \& Cía, París, 1930, n. 1358, p. 867).

(60) Cf. A. Stolz, op. cit., p. 189.

(61) H. U. v. Balthasar, "Ver, oír, leer en el ámbito de la Iglesia", op. cit., p. 566.

(62) A. Izquierdo, "Lectio divina: Método: (2) Meditatio", Ecclesia XXI, 2 (2007), p. 221.

(63) San Gregorio Magno, In Evang, Hom., 27,4; PL 76, 1207.

(64) A. Louf, A merced de su gracia, Propuestas de oración, Narcea, Madrid, 1996, p. 230. 
Asimismo la tradición monástica bizantina en el hesicasmo dispone de una expresión inigualable: "la inteligencia desciende al corazón”. La inteligencia abandona sus investigaciones autónomas y se une al corazón, entra dentro de él, y se encuentra con las demás potencias y facultades que han ascendido hasta él. Es allí donde el monje puede experimentar a Dios. "La Trinidad, tocando al alma con su gracia, la eleva por encima de sí misma y la diviniza; la hace participar del amor con que Dios se ama a sí mismo y de la ciencia con que se conoce a sí mismo. El hombre espiritual está dotado de disposiciones nuevas, de sentidos nuevos, que le connaturalizan con esa oscuridad divina e inaccesible al hombre carnal, y le permiten penetrar en ella" (65). Todo su ser entra en la vida de Dios y se integra por la acción del Espíritu, que se convierte en el factor de unificación. "Accende lumen sensibus. Infunde amorem cordibus”.

\section{SENTIDOS ESPIRITUALES EN LA MÍSTICA DE LOS MONJES MEDIE- VALES}

La mística de los monjes medievales al igual que la del monacato primitivo "siempre era una mística de la Escritura o una mística del culto" (66). Porque "el camino místico en el cristianismo siempre pasa por la Sagrada Escritura o por la Liturgia. La mística de la Escritura y la mística del culto eran el lugar donde las personas contemplativas tuvieron la experiencia de la unión con Dios" (67), porque en ambas esferas recuperaban y ejercitaban como veremos sus sentidos espirituales.

\section{1. Sentidos espirituales y lectio divina}

Anselmo de Cantorbery "presenta en su Proslogion un resumen clásico de la doctrina de los sentidos espirituales" (68):

“Todavía te ocultas a mi alma, Señor, en tu luz y felicidad; y por eso se bate ella todavía en sus tinieblas y en su miseria. Pues mira en torno a sí y no ve tu belleza. Escucha, y no oye tu armonía. Olfatea, y no percibe tu aroma. Saborea, y no reconoce tu sabor. Palpa, y no siente tu suavidad. En ti tienes estas cosas, Señor, de un modo inefable, que es propio tuyo; y a las cosas creadas por ti se has dado de modo sensible, que es propio de ellas; pero los sentidos de mi alma se han endurecido, se han embotado, se han obstruidos por la antigua flaqueza del pecado" (69).

A pesar de que Dios de algún modo posee, o mejor dicho, produce, estas cualidades que se perciben a través de los sentidos espirituales, el hombre no puede

(65) J. Daniélou, op. cit., p. 173.

(66) A. Grün, Las fuentes de la espiritualidad, Verbo Divino, Navarra, 2005, p. 17.

(67) Idem, p. 61.

(68) A. Stolz, op. cit., p. 164

(69) San Anselmo, Proslogion, c. XVII, EUNSA, Pamplona, 2002, pp. 53-54. 
percibirlas, ya que por el pecado ha perdido la sensibilidad interior del alma, quedándose solamente con la del cuerpo, y solo la curación, que significa padecer, experimentar las cosas de Dios, es la que despertará los sentidos dormidos, endurecidos, embotados y obstruidos. El prior de Bec así "expresa la liberación del conocimiento de los sentidos, del embotamiento debido al pecado original. Por la pérdida de la gracia del estado original quedó, en cierto modo, limitado a su objeto propio, mientras que antes participaba a su manera de la unión mística del espíritu con Dios" (70). Y es aquí donde entra en juego la lectio divina, porque en ella los monjes "aprendían a conocerse a sí mismos, a entrar en sí mismos y a considerar lo que tenían que cambiar" (71), favoreciendo la compunción del corazón bajo sus dos aspectos: el dolor de los pecados y el deseo de Dios (72).

La compunción tenía la propiedad de producir un efecto vital muy particular: restaurar la sensibilidad dormida. Gracias a este despertar los "ojos del corazón" (73), purificados por las lágrimas, recuperaban también la dimensión estética que habían perdido, integrando lo ético con lo estético, en una "delectación simultánea de la inteligencia y de los sentidos" (74); y a la vez, recibían una sensibilidad nueva, por la que volvían a ser atraídos por las cosas de Dios. Recuperaban la condición paradisíaca, el gusto natural en el que habían sido creados (75), y anticipaban de alguna manera la parusíaca, el gozo para el que estaban predestinados.

El monje alcanzaba en la lectio una comprensión de la Escritura proporcionada a su madurez interior (76). El principiante que vivía atado a los sentidos exteriores solo percibía el sentido exterior de la Escritura: el sentido literal. Se quedaba solo en la "carne" de la Palabra, porque vivía en la "carne" de sí mismo (77). A medida que, por la lectura y la meditación, penetraba en el sentido espiritual: sentido alegórico, y practicaba lo que le revelaba: el sentido tropológico o moral, su corazón se iba purificando y transfigurando, librándose de los condicionamientos y apegos sensitivos que lo enturbiaban, y adquiriendo así una pureza intelectiva que le hacía capaz de penetrar más y mejor por su meditación en los misterios de la fe (78).

(70) A. Stolz, op. cit., p. 247.

(71) J. Leclercq, "Formas de Oración y contemplación. II Occidente", en Espiritualidad cristiana. Desde los orígenes al siglo XII, Lumen, Bs. As., 2000, p. 432.

(72) Cf. J. Leclercq, "Lectio Divina", San Anselmo 5 (1982), p. 21; San Gregorio Magno dice que este dolor es producido por Dios en un acto de punción, pero puede ser ayudado por cuatro pensamientos que el hombre debe considerar en su corazón: ubi fui (dónde estuve: la miseria); ubi ero (dónde estaré: la muerte); ubi sum (dónde estoy: el mundo); ubi non sum (dónde no estoy: el cielo). Cf. San Gregorio Magno, Moralia in Job IV, 34, 2. Las dos primeras son fruto de la constatación de la propia miseria, los otros dos son fruto de la contemplación de Dios y suscitan el deseo de alcanzarlo.

(73) La expresión oculus cordis: "Omni cura servandus est a malitiae pulvere oculus cordis" (Moralia in Job I, 36, 119) es llamativa por cuanto es más común hablar de oculus mentis, Cf. J. Leclercq, Cultura y vida cristiana, Iniciación a los autores monásticos medievales, Sígueme, Salamanca, 1965 , p. 44.

(74) J. Maritain, Arte y Escolástica, Club de Lectores, Bs. As., s/d, p. 32.

(75) Cf. G. Castillo, "El don de la sabiduría", Coloquio 22 (2003), p.68.

(76) Cf. A. M. M. Fernández Gallar, "La "lectio divina"”, Revista Bíblica (1996) 11, pp. 64-65; Esmaragdo, Diadema monachorum 3, PL 102, 598.

(77) Cf. San Anselmo, Carta sobre la encarnación del Verbo, op. cit., p. 693.

(78) Cf. H. J. Padrón, "Lectio y ratio en el pensamiento de san Anselmo", en Metafísica y dialéctica en los períodos carolingio y franco (s. IX-XI), Eunsa, Pamplona, 2006, pp. 175-191. 
Esta pureza de corazón pedida, como don en la oración, y buscada, en la lucha ascética y las observancias monásticas, era a la vez condición para y resultado de su encuentro cotidiano y contemplativo con la Palabra (79). El velo de la impureza se rasgaba, la opacidad de la letra se disolvía, y a través de las palabras materiales empezaban a destellar los resplandores del Verbo eterno hasta, si Dios lo concede, tocar, oler, oír, gustar y ver la Bondad y la Belleza del Señor, que se presentía de algún modo en la contemplación del sentido anagógico. Como lo recuerda Otloh de Sankt Emmeran:

"Cuando uno se deja llevar por la lectio divina los ojos del hombre interior se abren. Entonces comprende lo que nunca había comprendido de las Escrituras y de todo lo demás. Se maravilla de haber sido hasta entonces tan sordo y tan ciego. Avanza más y más en la lectura santa, y lo que no leía sino por temor y deseo de perdón, ahora, cuando empieza a amar, pasa a conocer las maravillas de la sabiduría y la misericordia de Dios. Saborea cuán dulce es el Señor, medita su ley día y noche” (80).

El cartujo Guigo II por su parte ha expresado sapiencialmente este vínculo existente entre lectio divina, compunción, pureza de corazón y sentidos espirituales:

"En la lectura escucho: "Bienaventurados los limpios de corazón, porque ellos vera a Dios". He aquí una sentencia breve, pero dulce y llena de múltiples sentidos para alimento del alma, ofrecida como un racimo de uvas (81)... Pues el oído, de algún modo, forma parte de la lectura (82)... Inflamada por estas briznas, y estimulada por estos deseos, el alma, roto el frasco de alabastro, empieza a presentir la suavidad del perfume, no tanto todavía por el gusto cuanto, de algún modo por el olfato. De él deduce cuán suave sería sentir la experiencia de esa pureza, que por la meditación sabe que es tan gozosa (83)... La lectura pone, por así decirlo, el alimento sustancial en la boca, la meditación lo mastica y tritura, la oración obtiene gustar, la contemplación es la dulzura misma, que alegra y reconforta (84)... y cuanto más te conozco tanto más deseo conocerte, no ya en la corteza de la letra, sino en el sentido de la experiencia (85)... nos permite gustar un poco de su suavidad, y antes de que lleguemos a sentir plenamente se sustrae; de este modo revoloteando so-

(79) Cf. A. Hubert, "La meditación anselmiana como ejercicio teológico", en Sapientia Patrum, "Anales de la Facultad de Teología” LI, c. 2 (2000), pp. 301-302. El teólogo monástico “... necesita purificación del corazón (como condición) para meditar con fruto la Palabra de Dios, pero la meditatio a su vez tiene como efecto un incremento de la purificación del corazón al contacto con Dios y su Palabra (como fruto)" (A. Izquierdo, op. cit., p. 236).

(80) Liber de cursu spirituali 3, PL 146, 33.

(81) Guigo II, Carta sobre la vida contemplativa, traducción de A. M. Martín Fernández-Gallardo, ocso, en La Scala Claustralium de Guigo II el cartujo, Experiencia y método de la Lectio Divina, Monte Casino, Zamora, 1994, IV, p. 35.

(82) XIII, p. 46.

(83) V, p. 37.

(84) III, p. 45.

(85) VI, p. 39. 
bre nosotros con las alas extendidas, nos incita a volar, como diciendo: ya habéis gustado un poco cuán suave y dulce soy, pero si queréis ser saciados plenamente de esa dulzura, corred tras de mí al olor de mis perfumes, tened vuestros ojos levantados hacia donde yo estoy sentado a la diestra del Padre. Allí me veréis, no por espejo y enigma, sino cara a cara, y se alegrará plenamente vuestro corazón, y vuestra alegría nadie os la podrá quitar” (86).

La lectio consistía como podemos apreciar en un "probar las palabras con todos los sentidos", porque suponía un empeño particular en la aplicación de los sentidos corporales y espirituales para escudriñar los misterios escondidos en la Escritura.

Los monjes, siempre después de invocar al Espíritu Santo, tomaban reverentemente el libro entre sus manos, leían las primeras palabras y lo besaban (87). Leían la palabra para sí, pero en voz alta, por eso la oían, "realizaban la palabra en el signo" (88), saboreaban sus letras, contemplaban sus colores, iluminaciones y miniaturas. Cada término también tenía un sonido emotivo, por eso decían eran agradables y de sabor dulce. Meditar quería decir: memorizar, rumiar, repetir las palabras con el corazón, para que penetren cada vez más en él y lo siembren del sabor dulce de Dios, "dulcedo Dei" (89). A veces, para expresar lo mismo recurrían a otra imagen: "la lectio rompe en dos el vaso de alabastro que contiene el perfume de Dios; la meditatio lo huele; su añoranza la expresa la oratio; la contemplatio disfruta del perfume" (90).

Algunos tenían cierta predilección por uno u otro sentido, y otros preferían establecer gradaciones. Bernardo de Claraval habla de una jerarquía entre los sentidos espirituales como se da en los corporales (91), y establece una escala, todo un proceso, que va del tacto, lo más carnal, a la visión, el sentido propiamente escatológico (92). Nos detenemos solamente en la relación entre el oído y la vista, donde reaparece la relación entre lectio divina y puritas cordis:

“Dichosos los limpios de corazón, porque ellos verán a Dios; pues es necesario purificar el ojo para ver a Dios, como se nos dice: He purificado sus corazones con la fe (93)... Ahora, aquí, mientras no esté dispuesta la visión, debemos abrir el oído y ejercitarlo, para que acoja la verdad (94)... Quiera Dios abrirme el oído, para que penetre en mi corazón la palabra de la verdad, limpie mi vista, me prepare una visión gozosa... (95). No ignores que también el Espíritu Santo sigue este mismo proceso en la formación espiritual del

(86) X, p. 43.

(87) Cf. M. B. Pennington, Divina Mente, Lectio desde un monasterio, Bonum, Bs. As., 2002 , p. 11.

(88) H. U. v. Balthasar, "Ver, oír, leer en el ámbito de la Iglesia", op. cit., p. 580.

(89) Cf. A. Grün, Las fuentes de la espiritualidad, op. cit., p. 19.

(90) Idem, p. 23.

(91) San Bernardo, Sermones varios 90, 4, Obras completas VI, BAC, Madrid, 1987, p. 117.

(92) San Bernardo, Sermones sobre el Cantar de los Cantares 28, 8, V, p. 415.

(93) Idem. 28, 5, p. 413.

(94) Idem. 28, 6, p. 413.

(95) Ibidem. 
alma; antes de recrear la vista educa el oído... La fe purificará al que enturbió la impiedad; y al que cerró la desobediencia lo abrirá la desobediencia... es decir, la observancia de los mandamientos devuelve la inteligencia que había perdido por su transgresión" (96).

Guillermo de Saint Thierry propone una jerarquización similar, pero agregando de su propio pozo el vínculo entre sentidos espirituales y caridad:

"Cinco son los sentidos corporales o animales por los cuales el alma asegura la sensibilidad al cuerpo que anima. Comenzando de abajo hacia arriba son: el tacto, el gusto, el olfato, el oído y la vista. De modo semejante son cinco los sentidos espirituales, instrumentos de caridad para dar vida al alma: el amor carnal, es decir por nacimiento, el amor social, el amor natural, el amor espiritual, el amor de Dios. Por los cinco sentidos corporales, mediante la vida, el cuerpo esta unido al alma; por los cinco sentidos espirituales, mediante la caridad el alma está unida a Dios” (97).

Y compara luego prolijamente los sentidos con las formas de amor: asociando amor carnal con tacto (98), social con gusto (99); natural con olfato (100), espiritual con oído (101), y divino con vista (102).

Guerrico de Igny indica otro orden, enlazando los sentidos espirituales con la fe, la inteligencia y la experiencia:

"Pero el gusto del sabor no embriaga antes de que atraiga la suavidad del olor, ni tampoco alegra el gozo de la visión si primero no seduce [lo que cree piadosamente]. Si no creemos, tampoco entenderemos y no gustaremos cuán suave es el Señor (Sal 34, 9). La fe exhala el perfume; la experiencia gusta y disfruta" (103).

Y en otro sermón vincula: sabiduría, sentidos espirituales y lectio divina:

"Si después... alguien llega a la sabiduría, es decir, al sabor y gusto de las realidades eternas, y puede reposar y ver y, viendo, gustar cuán suave es el Señor, y le es revelado por el Espíritu lo que ni el ojo vio, ni el oído oyó ni el corazón del hombre pudo sospechar, diré que sin duda este ha sido magnífica

(96) Idem. 28, 7, p. 413.

(97) Guillermo de Saint Thierry, Naturaleza y dignidad del amor 19, op . cit., pp. 178-179.

(98) Cf. Idem. 20, 179.

(99) Cf. Idem. 21, 179-180.

(100) Cf. Idem. 22, 180.

(101) Cf. Idem. 23, 181

(102) Cf. Idem. 18, 178; 24, 181-182; 25, 182-183.

(103) Guerrico de Igny, Sermón 51, En la natividad de la Santísima Virgen María I: Flores y frutos de la vida cristiana $4,91-96$, p. 445.

(104) Guerrico, Sermón 13, Epifanía III, Grados por donde se llega a la luz de la sabiduría 7, op. cit., pp. 167-168. 
y gloriosamente iluminado... no todos entendemos esta palabra, pero el que pueda entender, entienda. No será condenado quien no entiende, pero el que no desee entender será inculpado de negligencia. El que lo desea, sepa que una oración fervorosa enciende la luz de la sabiduría, así como la lectura frecuente enciende la luz de la ciencia, con tal de que cuando leas emplees una antorcha ardiente, es decir la justicia de las obras y la experiencia de los sentidos espirituales" (104).

Todas estas diversas experiencias sensitivo-afectivo-cognoscitivas se presentaban durante la lectio divina, lugar originario donde la experiencia de Dios se hacía consciente y se desarrollaba, y que por eso era el elemento fundamental y fundante de la teología monástica. Bernardo de Claraval se manifiesta beneficiario muchas veces de las visitas del Verbo en la lectio divina. "La escucha de la palabra de Dios a través de la lectura orante de las Escrituras lleva al creyente a ver el rostro de Cristo, a tocar su presencia que se le impone, a gustar el consuelo del Espíritu, a llorar lleno de compunción... Es la experiencia espiritual concretísima" (105).

La sensibilidad espiritual del monje se iba afinando progresivamente a medida que el corazón se purificaba y dilataba gracias a la lectio. "La palabra de Dios, al tocar al alma, la despierta a la experiencia de las realidades divinas en que ella se complace" (106). Sin lectio divina, no hay puritas cordis, y sin puritas cordis no hay sensus cordis. "Beati mundo corde: quoniam ipsi Deum videbunt" (107).

La lectio divina era la medicina que curaba, el alimento que fortalecía, el vino que alegraba, el óleo que ungía y el fuego que encendía los sentidos espirituales, y estos una vez transfigurados se ponían a su servicio, colaborando con la memoria, la imaginación y la inteligencia, para ayudarla a profundizar en la comprensión de los sentidos espirituales del texto sagrado. Por caso, Amadeo de Lausana, en una de sus homilías (liturgia y lectio a la vez) marianas, al tratar en clave eclesial la unidad de los dos Testamentos reúne admirablemente las etapas de la vida espiritual (principiantes, proficientes y perfectos), los sentidos espirituales del lector (gusto, olfato y vista) y los sentidos del texto (literal, moral y místico):

“..."Tus pechos son mejores que el vino, perfumados con los mejores ungüentos” (Cant. 1, 1-2). La Iglesia, esposa de Cristo, tiene sus pechos en los dos Testamentos, por medio de los cuales les da a los pequeños la leche de la consolación y a los perfectos la leche de la exhortación... Estos pechos están perfumados como los mejores ungüentos porque los Testamentos de la Iglesia se manifiestan en palabras perfectas y, según la capacidad de las inteligencias, alimentan a unos con el envoltorio exterior del sentido literal e instruyen a otros con la suavidad del sentido moral, levantando a otros hacia las cumbres por medio de la comprensión del sentido místico. Exhalan, pues, como los

(105) E. Bianchi, op. cit., p. 31.

(106) J. Daniélou, op. cit., p. 111.

(107) Mt 5, 8 . 
mejores perfumes, porque a estos dos Testamentos se unen la gracia de la comprensión espiritual y la virtud de la caridad divina, que tienen la blancura de los lirios por el don de la inteligencia y exhalan el suave perfume del amor" (108).

Podemos entonces decir que los monjes medievales verificaban en ellos la palabra de manera sensible, espiritual y pneumática (109), lo que les permitía recorrer libremente los sentidos: literal, alegórico, tropológico y anagógico. Se percibe la circularidad virtuosa entre los sentidos espirituales del monje: "lector-leído" y los sentidos espirituales del texto sagrado: "leído-lector". "Sermone ditans guttura. Accende lumen sensibus. Infunde amorem cordibus".

\section{II.2. Sentidos espirituales y liturgia}

El teólogo de la liturgia Odo Casel, osb, distinguía dos formas diferentes de mística: la griega y la germánica (110). La primera era una mística de la "contemplación", de la observación de la imagen de Dios, de la "ebrietas". En el acto de observar el observador se unía con aquel que observaba: "Por los misterios nos hacemos uno con Dios, somos divinizados. El fin de la mística helénica es la participación en la vida divina y la unidad con Dios. El camino que conduce allí es la contemplación y la inserción en el misterio inefable de Dios, por la participación en la acción y en el canto litúrgico" (111).

Lo propio de la vista es la luz, percibe lo que se realiza en el espacio: lo físico, los signos, lo comunitario y lo horizontal. En las imágenes se contemplaba y se recibía una participación del misterio invisible. "Si hablamos de la experiencia de Dios en la observación, estamos frente a la paradoja de que Dios es por un lado ilimitado, infinito... y por el otro se muestra en infinidad de imágenes de este mundo y se presenta en imágenes que podemos ver" (112).

La vista es el sentido más objetivo, lo que significa dos cosas: por un lado, claridad interior e inteligibilidad, y por otro, distancia y separación. "El ojo precisa de la distancia para ver... incluso en los supremos éxtasis unificadores de la contemplación" (113). Pero entre los ojos que ven y los objetos "espirituales" vistos se establece por encima de la separación "una relación de visión interna de la interioridad ajena, de ver dentro..., hasta llegar a reconocer en el objeto la misma espiritualidad y la misma visión... es mirar en otro ojo, que también mira. Dos claridades, dos distancias se compenetran aquí, coinciden sin mezclarse" (114).

(108) San Amadeo de Lausana, Homilía sexta, La alegría de María en la Resurrección, en Homilías marianas, Monasterio Trapense de Azul-Claretiana, Bs. As., 1980, pp. 228-229.

(109) Cf. H. U. v. Balthasar, "Ver, oír, leer en el ámbito de la Iglesia", op. cit., p. 580.

(110) Cf. O. Casel, Le mystère du culte dans le christianisme, Cerf, Paris, 1946, pp.103 s.

(111) A. Grün, Salmodia y contemplación, Ediciones de la Abadía de San Benito de Luján, 2001, p. 4.

(112) A. Grün, Para experimentar a Dios, abre tus sentidos, op. cit., p. 75 s.

(113) H. U. v. Balthasar, "Ver, oír, leer en el ámbito de la Iglesia", op . cit., p. 562.

(114) Idem., p. 653. 
Esta mística tenía en cuenta lo natural, el intellectus fidei (115). "El Oriente es joánico, es la Iglesia de la visión... el Logos se llama Sentido e Idea..." (116). Esto no se expresaba solamente en la liturgia y la veneración de los iconos, sino también en una teología "filokálica" muy rica en bellas imágenes.

En cambio "la mística germánica se basa sobre métodos de ascesis y de concentración, y tiende a la unión con Dios por la práctica del silencio" (117). Es la mística de la escucha, porque el silencio cristiano es siempre correlativo a la escucha de Dios. La mística de la Reforma, por ejemplo, consideraba al acto de escuchar la Palabra como un elemento central de la experiencia de Dios, porque cree que la fe nace del escuchar e insta a la obediencia (118), "el oído aspira a una obediencia cada vez más perfecta y, en consecuencia, a una creaturidad que cada vez se distingue más humildemente del Creador" (119). Estamos entonces ante una mística de la "audición", de la "sobrietas".

Lo propio de la audición, que carece de objetividad en cuanto "no oímos objetos, sino que oímos sus expresiones y comunicaciones" (120), es el sonido; presta atención a lo que acontece en el tiempo, lo histórico, lo salvífico, lo individual y lo vertical, "lo oído cae sobre nosotros sin que hayamos dado nuestro consentimiento antes... lo oído ha pasado ya, ya no tenemos ningún poder sobre él” (121).

La mística del oído valoraba lo sobrenatural, el auditus fidei (122), que se manifestaba particularmente en la veneración de Escritura. "El Occidente es sinóptico-paulino, es la Iglesia de la audición... (por eso al Logos se lo llama) Verbum, Palabra" (123).

Ciertamente los dos caminos eran y son legítimos. Pero como tenemos una tendencia excesiva a reducir la mística solo a la germánica una mirada hacia atrás nos será de mucho provecho. En el medioevo monástico "oficio y contemplación, liturgia y contemplación eran mirados como una sola cosa. Liturgia y oración coral eran el lugar de la oración contemplativa, un cuadro en el cual los orantes alcanzaban una profunda experiencia de Dios" (124), mediante sus sentidos espirituales.

Parecería a primera vista que la espiritualidad litúrgica excluye o, por lo menos, ponía notables obstáculos al origen y al desarrollo de los actos y de los estados místicos (125), en lo que se refiere particularmente al uso de los signos sensibles y por consiguiente al ejercicio de los sentidos corporales y espirituales. Pero conviene recordar lo que Guigo I, prior y legislador de la Cartuja, enumeraba: "suavitates psalmodiarum, studia lectionum, fervores orationem, subtilitates meditationum, ex-

(115) Cf. I. Escribano Alberca, "Visión y audición en Romano Guardini", en Psicología religiosa y pensamiento existencial, Ensayos filosóficos-teológicos, Guadarrama, Madrid, 1963, p. 91.

(116) H. U. v. Balthasar, "Ver, oír, leer en el ámbito de la Iglesia", op. cit., p. 572.

(117) A. Grün, Para experimentar a Dios, abre tus sentidos, op. cit., ibidem.

(118) Cf. Idem., p. 78.

(119) H. U. v. Balthasar, "Ver, oír, leer en el ámbito de la Iglesia”, op. cit., p. 569.

(120) Idem., p. 564.

(121) Ibidem.

(122) Cf. I. Escribano Alberca, op. cit., idem.

(123) H. U. v. Balthasar, "Ver, oír, leer en el ámbito de la Iglesia", op. cit., p. 572.

(124) A. Grün, Salmodia y contemplación, ibidem.

(125) Cf. C. Vagaggini, El sentido teológico de la liturgia, Ensayo de liturgia teológica general, BAC, Madrid, 1965, p. 671. 
cessus contemplationum, baptismata lacrymarum" (126), relacionando la liturgia, especialmente la salmodia, con la lectio divina, la contemplación y la compunción. Porque como sostenía Anselm Stolz, osb: "la mística auténtica es siempre sacramental y se estructura sobre la liturgia" (127).

En el opus Dei, que era una celebración comunitaria en la presencia de Dios (128), se leían y escuchaban las lecturas de la Sagrada Escritura y los comentarios meditativos que de ellas habían hecho de los Santos Padres, intercalados con el canto de los salmos y de los himnos, que también eran una confesión del nombre de Dios (129).

Cantaba sabiamente los salmos (130) el monje que gustaba y saboreaba las palabras, el que las captaba y experimentaba con todos sus sentidos. El hombre entero actuaba en el canto de los salmos porque debía ver, oír, gustar, oler y saborear lo que cantaba. En la salmodia se adquiría el gusto de Dios (131), se experimentaba la dulcedo Dei, que "en la tradición espiritual... desempeña un papel importante. La experiencia de Dios deja en el hombre un sabor dulce. La dulcedo Dei se refiere siempre a la experiencia interior que se da en el propio corazón. Dios no es el sentimiento, pero deja sus huellas en el sentimiento" (132). Tampoco es la sensación, pero si quiere pasa por la sensación. Porque "no hay que confundir lo psicológico y emocional con lo espiritual, pero lo espiritual atraviesa lo psíquico e involucra los sentidos del cuerpo. Por tanto los sentidos espirituales no son solamente metáforas, sino que connotan la experiencia de la comunión con el Señor en los diversos aspectos en que se puede manifestar al espíritu humano: dulzura, fuerza, intimidad, adhesión amorosa, obediencia, presencia intensa" (133).

En la liturgia monástica medieval encontramos las místicas de la contemplación y de la audición conjugadas en una relación de complementariedad, ya que "si se consideran los signos sensibles de la liturgia por la parte de los diversos sentidos a los cuales se dirigen inmediatamente, se observa que predomina en ellos el ejercicio del oído y de la vista" (134), pero sin dejar olvidados los demás. "La liturgia no es posible -afirmaba von Balthasar- ni en el Oriente radical ni en el Occidente radical... sino únicamente por la figura íntegra de la Iglesia oriental-occidental" (135).

En el culto había palabras, silencios y cantos; gestos, colores y signos; toques, perfumes y sabores; todo un mundo de sensaciones simbólicas para los creyentes. Se hacía así patente la unidad entre cuerpo, alma y espíritu, por la interrelación entre sentidos corporales y espirituales. "Por medio de la economía sacramental la cele-

(126) Consuetudines c. 30; PL 153, 758.

(127) A. Stolz, op. cit., p. 268. “... la mística cristiana es realmente una mística sacramental. Es este un punto muy importante y, por desgracia, frecuentemente olvidado. El Sacramento nos da el germen, de donde brotará la vida mística, hasta alcanzar su suprema floración" (idem, pp. 62-63).

(128) Cf. RB XIX, 2.

(129) Cf. RB XIX, 7.

(130) Cf. $R B$ XIX, 4.

(131) Cf. A. Grün, Benito de Nursia, Espiritualidad enraizada en la tierra, Herder, Barcelona, 2003, p. 79.

(132) Idem, 144

(133) E. Bianchi, op . cit., p. 31.

(134) C. Vagaggini, op . cit., p. 67. Cf. San Agustín, De doctr. christ. II, 4.

(135) H. U. v. Balthasar, "Ver, oír, leer en el ámbito de la Iglesia", op. cit., pp. 575.576. 
bración del misterio involucra todos los sentidos del hombre, a la vez que exige también su afirmación y su transfiguración: se trata de percibir la realidad en Cristo" (136). En la presencia de Dios y por la obra del Espíritu Santo el hombre recuperaba, como ocurría también en la lectio divina, su unidad perdida.

Aún hoy el ritual del catecumenado de adultos, siguiendo "un bellísimo uso de tipo galicano y oriental” (137), repite la signatio crucis sobre los sentidos:

"Recibid la señal de la cruz en los oídos, para oír la voz del Señor”, "Recibid la señal de la cruz en los ojos, para ver la luz de Dios", "Recibid la señal de la cruz. en la nariz, para percibir el olor de la suavidad de Cristo", "Recibid la señal de la cruz en la boca para responder a la palabra de Dios", "Recibid la señal de la cruz en el pecho, para que Cristo habite en vuestros corazones por la fe" y "Recibid la señal de la cruz en la espalda, para cargar el suave yugo de Cristo".

Y en el sacramento de la unción de los enfermos se prescribe, siguiendo un Pontifical del siglo XIII, que se hagan unciones sacramentales sobre los sentidos:

"Por esta santa unción y por su piadosísima misericordia te perdone el Señor cuanto hubieres pecado con los ojos... Con los oúdos... Con el olfato... Con el gusto y la conversación... Con el tacto... Con los pies. Amén”.

Estos ejemplos de santificación de los sentidos son más que elocuentes, ya que se dan al inicio y al término de la vida cristiana. Para sanar y abrir los sentidos que han de tomar parte en la vida litúrgica terrestre; y para curarlos de sus condicionamientos y apegos ya que también participarán de algún modo en la liturgia celestial.

La espiritualidad litúrgica medieval era "sobria ebrietas", "característica típica de la vida mística" (138), por eso cantaban: "laeti bibamus sobriam ebrietatem Spiritus" (139), "bebamos con alegría de la sobria ebriedad del Espíritu”, era una mística de los sentidos espirituales. Tomaremos como único ejemplo el testimonio de una mujer.

"En la Edad Media, Santa Gertrudis [de Helfta] constituye como la encarnación de la espiritualidad litúrgica" (140), esta teóloga monástica del siglo XIII fue una maestra de la contemplación "que antes de remontar el vuelo hacia las cimas de la vida mística... se dejó llevar en alas de la Iglesia orante" (141), es decir, "tuvo la gracia de saborear la liturgia del cielo, porque la liturgia de la tierra era su vivir" (142), mostrando así "la perfecta unión entre liturgia, espiritualidad litúrgica y mística" (143).

(136) E. Bianchi, op. cit., p. 30.

(137) C. Vagaggini, op. cit., p. 298.

(138) A. Stolz, op. cit., p. 241.

(139) Himno ambrosiano Splendor paternae gloriae. Ex Brev. Rom. Feria II ad Laudes.

(140) G. Vagaggini, Biblia y espiritualidad litúrgica, Studium, Madrid, 1968, p. 152.

(141) Idem., 127.

(142) Ibidem.

(143) C. Vagaggini, op. cit., p. 674. Dedica especialmente a santa Gertrudis el capitulo XXII, pp. 696753. 
Su espiritualidad no se inscribe en una devotio, como la de Paray-Le-Monial que, en el corazón del jansenismo, revelaba la misericordiosa humanidad del Corazón de Jesús, concediendo un amplio espacio a los aspectos interiores, subjetivos e individuales, poniendo el acento en la reparación y en las prácticas de piedad que la acompañaban. La experiencia mística de Gertrudis, para quien la liturgia (opus Dei) está profundamente enraizada en su índole comunitaria y en la perspectiva bíblica (lectio divina) de la Historia de la Salvación, "está totalmente dentro de la dimensión litúrgica de su vida monástica; en el corazón de la oración coral de la comunidad; en el respiro orante del monasterio en que vive" (144). Por eso hablando de las gracias que brotan del Corazón de Cristo, cuenta y canta su propia experiencia con ocasión de las solemnidades litúrgicas y al hacerlo pone de manifiesto la relación existente entre liturgia, compunción y sentidos espirituales:

"Así pues, considerando de nuevo con gran admiración, y al mismo tiempo con agradecimiento, la tan gratuita bondad de Dios para con ella y reconociendo por otra parte la múltiple miseria de sus defectos, se sumergió, con el más grande desprecio de sí misma, en el profundísimo valle de la humildad que le era tan familiar, teniéndose por completamente indigna de toda gracia. Después de haber permanecido allí oculta por un rato, el Señor... parecía hacer salir de su Corazón una especie de conducto dorado, el cual, semejante a una lámpara, quedaba suspendido sobre aquella alma que estaba de esta manera abismada en el valle de la humildad... Habiendo dulcemente gozado de este modo durante un cierto tiempo de tales delicias y encontrándose, por la acción de la gracia divina, convenientemente preparada y colmada en perfección de todas las virtudes (por lo demás no suyas, sino de su Señor), oyó ella, con el oído de su corazón, una dulcísima voz, como de citaristas que acompañan dulcemente su cautivadora melodía tañendo sus cítaras (cf. Ap 14, 2), que le decía: "Tú, que eres mía, ven a mí; tú que eres mi bien, entra dentro de mí; tú que formas parte de mí, permanece conmigo”. Su dulce Señor se dignó darle el significado de este cantar... Mientras duró este dulcísimo gozo, ella sintió cómo una y otra vez penetraba en el Corazón del Señor, de una manera maravillosa, a través de este mencionado conducto, hallándose así felizmente en lo más íntimo de su Esposo y Señor. Lo que allí sintió, lo que vio, lo que oyó, lo que gustó o lo que tocó, solo ella lo sabe y también aquel que se dignó admitirla a tan excelente y sublime unión, es decir, Jesús, el Esposo del alma amante, "que está por encima de todas las cosas, Dios bendito por los siglos" (Rm 9, 5)" (145).

(144) C. Piccardo, Pedagogía viva, Cister novecientos años después, Monasterio Trapense Nuestra Sra. de Quilvo, 2002,p. 149.

(145) Gertrudis del Helfta, Mensaje de la Misericordia Divina (El Heraldo del amor divino), BAC, Madrid, 1999, L. III, c. 26, pp. 39-141. 
III. "VENI, CREATOR SPIRITUS... ACCENDE LUMEN SENSIBUS"

El encuentro cotidiano con Dios, en la Palabra durante la lectio divina y en el Misterio en el transcurso del Opus Dei, engendraban un hombre y una mujer nuevos, con su cuerpo, alma y espíritu unificados, que pudieron recuperar, gracias a la pureza de corazón, su sensibilidad perdida y así utilizar sus sentidos renovados, o mejor dicho, transfigurados, para experimentar a Dios y cantarle un cántico nuevo. De ahí la riquísima gama de referencias a los sentidos espirituales que hemos encontrado en los textos de los teólogos monásticos medievales.

El denominador común de todas estas experiencias sensitivas, afectivas y cognoscitivas, era, como hemos visto, la presencia y la acción del Espíritu Santo que "todo lo sondea hasta las profundidades de Dios" (1 Co 2,10), "enseña todo y recuerda todo" (Jn 14, 26), revelando a Jesucristo (146). Esta mística, que lo tenía como agente principal no era enemiga de los sentidos, sino más bien de todo aquello que les negaba su dinamismo y potencialidad trascendente, descartándolos o haciéndolos secundarios en la vida espiritual. "En el Evangelio, decía Roger Schutz, no hay dualismo materia-espíritu... El combate de la vida no es una lucha del espíritu del hombre por someter su cuerpo, sino la lucha del Espíritu de Dios por someter a El todos los poderes del hombre" (147).

Por la lectio divina y el opus Dei "el Espíritu Santo -principio operante de la contemplación mística- adquiere, de algún modo, dominio sobre las demás facultades, las cuales, por su parte, experimentan en sí el influjo unificador de Dios" (148). Por eso cantaban insistentemente (149): "Veni, Creator Spiritus, mentes tuorum visita... Accende lumen sensibus... Per te sciamus da Patrem noscamus atque Filium, te utriusque Spiritum credamus omni tempore”.

Al aproximarnos a los sentidos espirituales en algunos pocos testimonios de los siglos XI al XIII hemos experimentado una renovada admiración ante el bello ejemplo de la posibilidad de la síntesis entre Sagrada Escritura, Tradición y Liturgia, entre fe, razón y experiencia, y entre teología y vida que nos recuerda que la teología monástica era intellectus fidei y affectus fidei (150), integrando sensibilidad, afectividad y racionalidad, porque la inteligencia de la fe esta siempre unida a la experiencia del amor.

(146) “Acercarse a él por múltiples caminos, aprender a verlo, tal es la primera y principalísima misión del estudio de la teología. Porque este estudio no habla, en el fondo, de nada absoluto, si las ideas de la ciencia no se refieren a la realidad de nuestra vida. Pero cuanto más lo conocemos, más cosas nos dicen todas las palabras de la revelación y tanto más se convierten en caminos hacia él y de él hacia los hombres" (J. Ratzinger, Servidor de vuestra alegría, Ágape, Bs. As., 2005, pp. 67-68).

(147) R. Schutz Marsauche, Vivir en el hoy de Dios, Estela, Barcelona, 1964, p. 42.

(148) A. Stolz, op . cit., p. 247.

(149) Se cantaba inicialmente en Vísperas de Pentecostés, pero un manuscrito del s. XI lo tiene en Laudes y Vísperas, otros dos en Laudes y alguno lo coloca en Maitines. Su uso en Tercia comenzó en Cluny. El antiguo Ordinario de Laon indica su uso en todas las horas. Las monjas del Paraclete repetían la primera estrofa siete veces en Tercia, cinco en Sexta, y tres en Nona. En el Concilio de Reims en 1049, que presidió León IX, se cantó en la tercera sesión; y se encuentra en varios pontificales del mismo siglo.

(150) Cf. C. Izquierdo, "La teología, intellectus y affectus fidei”, Ciencia tomista 397 (1995), pp. 307327. 
Conviene siempre acordarse de lo que sabiamente decía Guerrico de Igny, de quien celebramos los ochocientos cincuenta años de su tránsito:

“... como todo banquete demasiado prolongado y variado se torna fastidioso, pondremos fin a nuestro discurso. A vosotros os corresponde recoger los fragmentos sobrantes, esto es, las cosas más ingeniosas que se me escaparon de las manos; a vosotros tanto como a mí cantar a aquel que nos alimenta a todos: bendito sea Dios en sus dones, que vive y reina por los siglos de los siglos” (151).

\title{
RESUMEN
}

A partir de dos hechos: las reiteradas referencias a la doctrina de los sentidos espirituales en los teólogos monásticos medievales y el olvido de la misma por parte de los autores posteriores, nos aproximamos a este "conocimiento experimental" (mística), desde la filosofía y la teología, partiendo de algunos testimonios de los siglos XI al XIII (I), especialmente los referidos a la lectio divina (II. 1) y al opus Dei (II. 2), implorando también con ellos "Accende lumen sensibus".

Palabras clave: Experiencia (o sentidos espirituales), mística, lectio, liturgia.

\begin{abstract}
Starting from two facts-the reiterated references to the doctrine of the spiritual senses in medieval monastic theologians and the neglect of the same on the part of later authors-the author of this article approaches this "experiential (mystical) knowledge" from philosophy and from theology. He begins with some testimonies from the $11^{\text {th }}$ and $12^{\text {th }}$ centuries, especially those referring to the lectio divina and to the opus Dei, imploring along with them "Accende lumen sensibus".
\end{abstract}

Key words: Experience (or Spiritual Senses), Mysticism, lectio, Liturgy. 